\title{
A (IN) EXISTÊNCIA DE CONFLITO ENTRE OS DIREITOS À LIBERDADE RELIGIOSA E À SAÚDE: O DEVER DO ESTADO DE FORNECER TRATAMENTO ALTERNATIVO PARA TESTEMUNHAS DE JEOVÁ
}

THE LACK OF CONFLICT BETWEEN RIGHTS TO RELIGIOUS FREEDOM AND HEALTH: THE DUTY OF THE STATE TO PROVIDE ALTERNATIVE TREATMENT FOR JEHOVAH'S WITNESSES

LA (IN) EXISTENCIA DE CONFLICTO ENTRE LOS DERECHOS A LA LIBERTAD RELIGIOSA Y LA SALUD: EL DEBER DEL ESTADO DE PROPORCIONAR TRATAMIENTO ALTERNATIVO PARA LOS TESTIGOS DE JEHOVÁ

Augusto César Leite de Resende ${ }^{1}$ Carlos Augusto Alcântara Machado ${ }^{2}$ Lara Costa Barroso Andrade de Oliveira ${ }^{3}$

\section{RESUMO}

O presente trabalho objetiva demonstrar a constitucionalidade do custeio pelo Estado de tratamentos alternativos independentes de transfusão sanguínea a Testemunhas de Jeová, ainda que não abarcados pela rede pública de saúde, por meio do estudo do caso do Recurso Extraordinário $n^{\circ} 979.742$, cujo julgamento encontra-se pendente no Supremo Tribunal Federal. Para tanto, realizou-se pesquisa qualitativa teórica, por intermédio de revisão bibliográfica de livros, artigos científicos, dissertações de mestrado e doutrina jurídica, bem como de análise dos textos do site oficial mundial das Testemunhas de Jeová, da jurisprudência e a legislação nacional pertinente ao tema. Concluiu-se, a partir das informações colhidas, que o financiamento de terapias compatíveis com as crenças das Testemunhas de Jeová é um mister, a fim de assegurar os direitos fundamentais à liberdade religiosa, à saúde e à igualdade e de

\footnotetext{
${ }^{1}$ Doutor em Direito pela Pontifícia Universidade Católica do Rio Grande do Sul. Mestre em Direito Econômico e Socioambiental pela Pontifícia Universidade Católica do Paraná. Especialista em Direito Público pela Universidade Sul de Santa Catarina. Atualmente é professor de Direitos Humanos e Fundamentais do Curso de Graduação em Direito da Universidade Tiradentes - UNIT. Tem experiência na área de Direito, com ênfase em Direitos Humanos, Constitucional e Administrativo. augusto@mpse.mp.br - https://orcid.org/0000-0003-17198685.

2 Professor de Direito Constitucional dos Cursos de Graduação e Pós-Graduação Stricto Sensu da Universidade Federal de Sergipe - UFS (São Cristóvão, SE, Brasil) e da Universidade Tiradentes - UNIT (Aracaju, SE, Brasil). Doutor em Direito pela Pontifícia Universidade Católica de São Paulo - PUC/SP. Mestre em Direito pela Universidade Federal do Ceará - UFC. Procurador de Justiça do Ministério Público de Sergipe. cmachado@infonet.com.br - https://orcid.org/0000-0002-2834-9699.

3 Advogada. Graduada em Direito pela Universidade Tiradentes - UNIT. lcbaoliveira@gmail.com https://orcid.org/0000-0002-4404-8255.

Revista Direitos Democráticos \& Estado Moderno |Faculdade de Direito da PUC-SP https://revistas.pucsp.br/index.php/DDEM | No. 02 | p.51-77 | Jan. / Jun. 2021
} 
concretizar o objetivo da República Federativa brasileira de construir uma sociedade fraterna com a garantia adicional de um melhor custo-efetividade dos tratamentos.

Palavras-chave: Liberdade religiosa. Saúde. Transfusão sanguínea. Testemunhas de Jeová. Proporcionalidade.b

\begin{abstract}
The present work aims to demonstrate the constitucionality of State funding of alternative bloodless treatments to Jeovah's Witnesses, even if not covered by the public health system, by studing the case of the Extraordinary Appeal $n^{\circ}$ 979.742, which is currently pending of judgement in the Federal Supreme Court. In order to achieve this goal, a qualitative theoratical research was carried out through bibliographic review of books, scientific articles, master's dissertations and legal doctrine, as well as analysis of the texts from the Jeovah's Witnesses official world website, case law and relevant national legislation to the theme. It was concluded from the gathered information that the financing of therapies compatible with Jeovah's Witnesses beliefs is a must in order to secure the fundamental rights to religion freedom, health and equality and to achieve the Brazilian Federal Republic's goal of building a fraternal society with the additional garantee of better cost-effectiveness of treatments.
\end{abstract}

Keywords: Freedom of religion. Health. Blood transfusion. Jeovah Witnesses. Proportionality.

\title{
RESUMEN
}

El presente trabajo tiene como objetivo demostrar a los testigos de Jehová la constitucionalidad del costo por parte del Estado de tratamientos alternativos independientes de transfusión de sangre, incluso si no están cubiertos por la red de salud pública, a través del estudio del caso de Apelación Extraordinaria No. 979.742, cuyo juicio es pendiente ante la Suprema Corte Federal. Con este fin, se llevó a cabo una investigación teórica cualitativa, a través de la revisión bibliográfica de libros, artículos científicos, disertaciones de maestría y doctrina legal, así como el análisis de los textos del sitio web mundial oficial de los testigos de Jehová, la jurisprudencia y la legislación nacional pertinente al tema Se concluyó, a partir de la información recopilada, que el financiamiento de terapias compatibles con las creencias de los testigos de Jehová es un deber para garantizar los derechos fundamentales a la libertad, la salud y la igualdad religiosa y para alcanzar el objetivo de la República brasileña para construir una sociedad fraterna con la garantía adicional de una mejor rentabilidad de los tratamientos.

Palabras-clave: Libertad religiosa. Salud. Transfusión de sangre. Testigos de Jehová. Proporcionalidad.

\section{INTRODUÇÃO}

A religião, em sentido denotativo, pode ser conceituada como a crença em um princípio superior e sobrenatural, responsável, dentre outras coisas, pelo presente, passado e futuro das vidas na Terra, humanas ou não. Ela representa para os seus fiéis não só uma certeza acerca do significado da existência do homem, mas também uma bússola tanto coletiva, quanto individual de valores morais, sociais, culturais, políticos e econômicos. 
Destarte, até o surgimento do Estado laico no conhecido século das luzes, a religião justificava não só a criação de nações, a partir da identificação entre seus cidadãos e o cultuado, mas também o desfazimento delas, pelo entendimento dogmático de que somente uma fé era verdadeira e digna e, portanto, as que não o eram deveriam ser banidas e seus adeptos apenados - fosse com a conversão religiosa forçada ou com a escravidão, fosse com a perseguição e a execução dos denominados "hereges".

Dessa forma, a partir do contexto supracitado de desvinculação do poder político do Estado do espiritual da Igreja, surge a importância da liberdade religiosa enquanto direito, com a finalidade de assegurar aos crentes de diferentes credos e aos descrentes, a possibilidade de existir e coexistir em sociedade.

No Brasil, embora a constitucionalização da referida liberdade tenha ocorrido tão logo a promulgação da primeira Constituição Federal republicana, em $1891^{4}$, a concretização deste direito permanece um desafio, sobretudo aos seguidores de religiões minoritárias, cujas peculiaridades de convicção presentam aos membros da comunidade jurídica constantes debates acerca do Direito e da Justiça, como a das Testemunhas de Jeová e sua recusa consciente à transfusão de sangue.

Para as Testemunhas de Jeová, o recebimento de sangue alheio é proibido expressamente pelos escritos bíblicos e, portanto, por Deus. Com efeito, os fiéis deste credo creem que devem abster-se da ingestão por quaisquer vias deste tecido, venal ou não. Entretanto, não raro os tratamentos que atendem a essa exigência encontram-se indisponíveis no serviço de saúde pública, fato este responsável por diversas demandas judiciais em face da das pessoas políticas estatais, cujo objetivo autoral é garantir os direitos fundamentais à saúde e à liberdade religiosa.

É neste cenário fático e jurídico que a controvérsia do Recurso Extraordinário $\mathrm{n}^{\circ}$ 979.742/AM se insere, ao levar-se à Corte Suprema os seguintes questionamentos, os quais coincidem com os norteadores da presente pesquisa: é juridicamente possível garantir a liberdade religiosa e, de tal modo, uma vida digna às Testemunhas de Jeová, assegurando, outrossim, a prestação de serviço público de saúde universal e isonômico? O Estado tem o dever

\footnotetext{
${ }^{4}$ A Constituição Imperial de 1824 contemplava norma que somente permitia o culto doméstico e particular de qualquer religião, considerando que o país possuía religião oficial: a católica ("Art. 5. A Religião Catholica Apostolica Romana continuará a ser a Religião do Imperio. Todas as outras Religiões serão permitidas com seu culto doméstico, ou particular em casas para isso destinadas, sem forma alguma exterior do Templo" (BRASIL, 1824).
}

Revista Direitos Democráticos \& Estado Moderno |Faculdade de Direito da PUC-SP https://revistas.pucsp.br/index.php/DDEM | No. 02 | p.51-77 | Jan. / Jun. 2021 
Augusto César Leite de Resende; Carlos Augusto Alcântara Machado e Lara Costa Barroso Andrade de Oliveira

constitucional de fornecer às Testemunhas de Jeová tratamentos alternativos sem o uso de sangue?

Frente ao explanado, o presente artigo científico objetiva, de modo geral, demonstrar a constitucionalidade do custeio pelo Estado de tratamentos sem transfusão de sangue a Testemunhas de Jeová e, de modo específico, analisar os direitos fundamentais à liberdade religiosa e à saúde sob a ótica da Carta Magna de 1988; compreender a atuação do princípio jurídico da fraternidade na proteção dos direitos de minorias, em especial, a das Testemunhas de Jeová; e averiguar a factibilidade da garantia de tratamentos sem utilização de tecido sanguíneo pelo Estado sob o viés de custo-efetividade.

Para alcançar tais propósitos, realizou-se pesquisa qualitativa teórica, cujas conclusões foram encontradas, por meio do método hipotético-dedutivo, primordialmente por intermédio da revisão bibliográfica de livros, artigos científicos, dissertações de mestrado e doutrina jurídica e do estudo do Recurso Extraordinário no 979.742/AM, bem como da leitura de textos explicativos constantes no site oficial mundial de Testemunhas de Jeová, da legislação brasileira e da jurisprudência nacional sobre o tema.

\section{O RECURSO EXTRAORDINÁRIO No 979.742/AM E O RECONHECIMENTO DA SUA REPERCUSSÃO GERAL}

Protocolado em 21 de junho de 2016 pela União em face de Heli de Paula Souza e do Município de Manaus, o Recurso Extraordinário 979.742/AM devolveu ao Supremo Tribunal Federal a matéria abordada em decisão proferida pela Turma Recursal dos Juizados Federais do Amazonas e de Roraima, a qual condenara solidariamente a recorrente, o Estado do Amazonas e o Município de Manaus a custear a cirurgia de artroplastia total primária cerâmica, na modalidade Tratamento Fora do Domicílio (TFD), em hospital público ou particular, que executasse o procedimento sem utilização de transfusão sanguínea para a autora, inclusa cobertura assistencial integral; e a financiar, também, as passagens áreas, hospedagem, ajuda de custos, alimentação e outras despesas, a ela e a um acompanhante, em virtude da paciente demandante ser Testemunha de Jeová (BRASIL, 2017).

O acórdão recorrido, que manteve a sentença incólume, refutara as teses da União de afronta à isonomia no direito sanitário e à razoabilidade, devido, respectivamente, à inexistência de provas nos autos que comprovassem inobservância de ordem cronológica ou priorização da requerente quanto aos atendimentos para quadros clínicos similares a serem realizados na https://revistas.pucsp.br/index.php/DDEM| Nº. 02 |p.51-77 | Jan. / Jun. 2021 
mesma modalidade requestada, bem como à previsão na prática médica de tratamento com pleno atendimento à peculiaridade que se busca evitar (BRASIL, 2017). Ademais, rememorara o colegiado o fim precípuo dos direitos fundamentais, isto é, o alcance à dignidade humana, motivo pelo qual, se permitido e possível pela técnica, deve-se atender ao direito à saúde com compatibilidade à liberdade religiosa (BRASIL, 2017).

Nesse cenário, com fulcro no art. 102, inciso III, alíneas "a"e "b", da Constituição Federal, a insurgência do ente federal embasou-se em três argumentos: a) o primeiro, preliminar, refere-se a sua ilegitimidade para figurar como ré, diante da descentralização que consolida o Sistema Único de Saúde, prevista no art. 198, inciso I, da Carta Magna; b) o segundo, por sua vez, trata-se da suposta violação ao princípio da isonomia, constante no art. 196, caput, da Lex Fundamentalis, pela compreensão de que a condenação da Administração Pública a efetivar o pleito exordial não só priorizaria um cidadão frente aos outros que de igual modo aguardam tratamento no serviço público, mas também transmitiria indiretamente ao Poder Judiciário o poder de ordenar as políticas públicas na área da saúde.

O terceiro, e último, foi a ofensa ao princípio da razoabilidade, em virtude da imprevisibilidade de complicações durante o procedimento cirúrgico que impossibilitam os demandados de assegurarem a não ocorrência de transfusão sanguínea (BRASIL, 2017). Entretanto, em exame de admissibilidade no juízo de origem, foi negado seguimento à tese de preliminar, razão pela qual somente as outras duas alegações foram submetidas à apreciação da Corte Suprema (BRASIL, 2017).

Após a expedição de parecer pela Procuradoria-Geral da República pelo desprovimento do recurso, diante da ausência de provas da impossibilidade de realização do procedimento sem a transfusão de sangue, os autos seguiram conclusos para o Ministro Luís Roberto Barroso, relator do processo em tela, que, em 29 de junho do ano seguinte, manifestou-se pela admissão do recurso e o reconhecimento da repercussão geral do tema - Tema 952 (BRASIL, 2017) ${ }^{5}$. O

\footnotetext{
5 "Direito constitucional e sanitário. Recurso extraordinário. Direito à saúde. Custeio pelo Estado de tratamento médico diferenciado em razão de convicção religiosa. Repercussão geral. 1. A decisão recorrida condenou a União, o Estado do Amazonas e o Município de Manaus ao custeio de procedimento cirúrgico indisponível na rede pública, em razão de a convicção religiosa do paciente proibir transfusão de sangue. 2. Constitui questão constitucional relevante definir se o exercício de liberdade religiosa pode justificar o custeio de tratamento de saúde pelo Estado. 3. Repercussão geral reconhecida". (RE 979742 RG, Relator(a): Min. ROBERTO BARROSO, julgado em 29/06/2017, Processo Eletrônico DJe-168 DIVULG 31-07-2017 PUBLIC 01-08-2017 ). Disponível em:

http://www.stf.jus.br/portal/jurisprudencia/listarJurisprudencia.asp?s1=\%28RE\%24\%2ESCLA\%2E+E+979742 \%2ENUME\%2E\%29+OU+\%28RE\%2EPRCR\%2E+ADJ2+979742\%2EPRCR\%2E\%29\&base=baseRepercussa o\&url=http://tinyurl.com/hwfje6x. Acesso em: 26 fev. 2020.

Revista Direitos Democráticos \& Estado Moderno |Faculdade de Direito da PUC-SP https://revistas.pucsp.br/index.php/DDEM | No. 02 | p.51-77 | Jan. / Jun. 2021
} 
Augusto César Leite de Resende; Carlos Augusto Alcântara Machado e Lara Costa Barroso Andrade de Oliveira

entendimento adveio da compreensão da transcendência e relevância da questão constitucional aventada no pleito recursal econômica, política, social e juridicamente, pois exige ponderação entre os direitos fundamentais à liberdade religiosa e à saúde, sobretudo à igualdade na prestação dessa última, a fim de resolvê-lo (BRASIL, 2017).

O referido recurso extraordinário, quando da conclusão do presente artigo $^{6}$, ainda não se encontrava definitivamente julgado pelo Supremo Tribunal Federal e, após relatado o andamento processual e o teor de suas peças mais importantes, debruça-se sobre o estudo essencial da controvérsia constitucional de que trata o RE $n^{\circ}$ 979.742. Insta compreender, primeiro, no que consiste a recusa consciente das Testemunhas de Jeová à transfusão sanguínea e o seu embasamento bíblico. Depois, o motivo pelo qual o fornecimento de tratamento harmônico a essa peculiaridade religiosa pelo serviço público de saúde apresenta-se, aparentemente, como problema.

De acordo com o site oficial mundial dos seguidores desta religião, a abstinência de recebimento de sangue alheio por qualquer via é um mandamento divino prescrito em algumas passagens bíblicas tanto no Velho, quanto no Novo Testamento, fomentadas pela percepção de que esse tecido simboliza aquilo somente dado por Jeová: a vida (JW, 2019a). A proibição, por sua vez, engloba o plasma, os glóbulos vermelhos, os glóbulos brancos e as plaquetas, componentes do sangue, e refere-se tanto às transfusões halogênicas, quanto às autólogas préoperatórias, ou seja, respectivamente, as advindas de um terceiro doador e as reinfundidas do próprio transplantado (JW, 2019b). A transferência de frações sanguíneas, tais como hemoglobina e albumina, entretanto, é permitida, ante a omissão bíblica sobre elas (JW, 2019c). De tal modo, cabe ao fiel optar pelo seu recebimento.

Dessa forma, cumpre destacar os seguintes trechos bíblicos, demonstrativos da interpretação das Testemunhas de Jeová sobre o tema: "porquanto a vida de toda carne é o seu sangue; por isso tenho dito aos filhos de Israel: Não comereis o sangue de nenhuma carne, porque a vida de toda carne é o seu sangue; qualquer que o comer será extirpado" (LEVÍTICO, 17:14); "mas escrever-lhes que se abstenham das contaminações dos ídolos, da fornicação, do que é sufocado e do sangue" (ATOS, 15:20) e "porque a vida da carne está no sangue; pelo que vo-lo tenho dado sobre o altar, para fazer expiação pelas vossas almas; porquanto é o sangue que fará expiação pela alma” (LEVÍTICO, 17:11).

Assim, como o texto da Constituição Federal vigente torna imperiosa a proteção ao direito individual à liberdade de crença, é dever estatal, sempre que possível, respeitar e, por

\footnotetext{
${ }^{6} 27$ de fevereiro de 2020.

Revista Direitos Democráticos \& Estado Moderno | Faculdade de Direito da PUC-SP https://revistas.pucsp.br/index.php/DDEM | No. 02 | p.51-77| Jan. / Jun. 2021
} 
conseguinte, efetivar, atos congruentes com as convicções dos seus cidadãos, in casu, o desejo da paciente de abster-se à doação sanguínea em cirurgia ortopédica. A partir desse contexto, a celeuma enfrentada no Recurso Extraordinário no 979.742 nasce da aparente colisão o direito fundamental à liberdade religiosa e o direito fundamental à saúde, tendo em vista a notória situação calamitosa dos cofres públicos e a longa lista de espera para atendimento do Sistema Único de Saúde (SOBRINHO, 2018).

Nesse sentido, a análise a ser realizada pelo Supremo Tribunal Federal, como explanado pelo ministro-relator, gira em torno de definir "não apenas qual bem constitucional deve preponderar no caso concreto, mas também em que medida o intensidade deve preponderar" (BRASIL, 2017, p. 6), pois se, por um lado, o direito à saúde deve-se adaptar à autonomia do paciente, por outro, o direcionamento constante de recursos públicos para pretensões individuais implicaria em falência do serviço público, o qual atende a uma coletividade. Avaliase a seguir, portanto, o desenlace dessa controvérsia.

\section{DIREITOS FUNDAMENTAIS EM COLISÃO: A PREPONDERÂNCIA ENTRE PRINCÍPIOS}

$\mathrm{Na}$ atualidade, compreende-se que a norma jurídica é gênero dos quais são espécies as regras e os princípios (ABBOUD; CARNIO; OLIVEIRA, 2019). A atual dicotomia que divide a norma jurídica em regras e princípios encontra suas raízes no jusfilósofo norte-americano Ronald Dworkin. Os princípios e as políticas são padrões que não são regras (DWORKIN, 2010). A política é "aquele tipo de padrão que estabelece um objetivo a ser alcançado, em geral uma melhoria em algum aspecto econômico, político ou social da comunidade" (DWORKIN, 2010, p. 36). Já o princípio se apresenta como “um padrão que deve ser observado, não porque vá promover ou assegurar uma situação econômica, política ou social considerada desejável, mas porque é uma exigência de justiça ou equidade ou alguma outra dimensão da moralidade" (DWORKIN, 2010, p. 36). E por fim, nas palavras de Ronald Dworkin (2010, p. 39):

As regras são aplicáveis à maneira do tudo-ou-nada. Dados os fatos que uma regra estipula, então ou a regra é válida, e neste caso a resposta que ela fornece deve ser aceita, ou ela não é válida, e neste caso em nada contribui para a decisão.

Os princípios jurídicos possuem uma dimensão de peso ou importância que as regras jurídicas não têm e, por isso, se houver eventual conflito entre princípios, a sua solução se dará 
Augusto César Leite de Resende; Carlos Augusto Alcântara Machado e Lara Costa Barroso Andrade de Oliveira

através da aplicação de um, à luz das peculiaridades do caso concreto, sem a invalidação do outro, que continua vigente na ordem jurídica, ao passo que se duas regras entram em conflito, uma será inválida (DWORKIN, 2010, p. 42-43).

Inspirando-se na teoria de Ronald Dworkin, o jurista alemão Robert Alexy constrói sua teoria da norma, igualmente dividindo a norma jurídica em regras e princípios. Sob essa premissa, de acordo com Alexy, as regras veiculam obrigações, proibições ou permissões de aplicação direta e integral num sistema tudo ou nada, de modo que, ou são inteiramente satisfeitas ou insatisfeitas. Os princípios, por sua vez, estabelecem determinações a serem efetivadas em sua máxima potência dentro não só da conjuntura fática, mas também da jurídica em análise, razão pela qual, nominados como mandamentos de otimização, podem ser ponderados e concretizados em diferentes graus (ALEXY, 2008, p. 91).

Diante dos conceitos assinalados, compreende-se ser inviável a existência de duas regras com conteúdo conflitante, salvo quando uma delas for exceção da outra. Do contrário, a invalidade da primeira ou da segunda deverá ser declarada e sua permanência no ordenamento jurídico extirpada. Isso, porque a natureza das regras exige a incidência inteira e direta da norma, o que torna inconcebível a manutenção de determinações contrapostas de maneira distinta da supracitada (ALEXY, 2008).

Assim, a fim de reconhecer qual regra deve ser preterida, devem ser utilizadas técnicas como a da prevalência da lei especial sobre a lei geral (lex specialis derogat legi generali) ou a da lei posterior sobre lei anterior (lex posteriori derogat legi priori) ou, ainda, pode ser avaliada a importância de cada norma em conflito (ALEXY, 2008), sem se descuidar do uso do princípio do pro homine quando há conflito entre um tratado de direitos humanos e a Constituição Federal, ocasião em que aplicar-se-á a norma mais favorável ao ser humanos. (RESENDE, 2019).

Diferentemente ocorre em uma colisão entre princípios. Como espécie normativa cuja aplicação permite juízo ponderativo, os mandamentos de otimização podem resguardar conteúdos opostos e continuar juridicamente válidos, independente da inserção de cláusula de exceção, pois sua satisfação enquanto direito é obtida em diferentes intensidades que não, necessariamente, a maior e absoluta. Nesse sentido, a resolução de um confronto desse gênero requer a cedência, em determinado grau, de um princípio a outro, o qual, quando considerado no caso concreto, precede-o em peso (ALEXY, 2008).

Infere-se, dessa forma, que as circunstâncias fáticas delineadoras de uma lide são ponto chave para definição não só de qual princípio deverá prevalecer, mas também, por efeito, de https://revistas.pucsp.br/index.php/DDEM | No. 02 | p.51-77 | Jan. / Jun. 2021 
quais consequências jurídicas serão aplicáveis à situação judicializada e aos seus pares. Esses fatos determinantes estabelecem, sempre que presentes, regra quanto ao resultado jurídico do confronto de dois princípios específicos (ALEXY, 2008).

Sobre regras e princípios, explica Robert Alexy (2008, p. 93-94):

Se dois princípios colidem - o que ocorre, por exemplo, quando algo é proibido de acordo com um princípio e, de acordo com outro, permitido - um dos princípios terá que ceder. Isso não significa, contudo, nem que o princípio cedente deva ser declarado inválido, nem que nele deverá ser introduzida uma cláusula de exceção. Na verdade, o que ocorre é que um dos princípios tem precedência em face do outro sob determinadas condições. Sob outras condições a questão da precedência pode ser resolvida de forma oposta. Isso é, o que se quer dizer quando se afirma que, nos casos concretos, os princípios têm pesos diferentes e que os princípios com maior peso têm precedência. Conflitos entre regras ocorrem na dimensão da validade, enquanto as colisões entre princípios - visto que só princípios válidos podem colidir - ocorrem, para além dessa dimensão, na dimensão do peso.

Os direitos fundamentais, dentro desse contexto, possuem caráter duplo, pois as normas que os dispõem veiculam, ao mesmo tempo, regra e princípio de que devem ser avaliados diante da aplicação da norma. Entende-se que embora os direitos fundamentais resguardem conteúdo de aplicação direta, tal qual regra, existe cláusula restritiva inerente a eles que permite sua ponderação ou sopesamento com normas colidentes, como somente os princípios facultam (ALEXY, 2008). Destarte, quando direitos fundamentais se opõem - o que só pode ocorrer perante um caso concreto - a solução do impasse será realizada de igual modo a uma colisão principiológica.

Ante ao exposto, observa-se que a questão constitucional abordada no recurso extraordinário $\mathrm{n}^{\circ}$ 979.742/AM, por envolver contraposição entre os direitos fundamentais à liberdade religiosa e à saúde, somente pode ser resolvida através da técnica de ponderação de interesses (SILVA NETO, 2008). Para alcançar tal fim, entretanto, é necessário não só conhecer, separadamente, a proteção constitucional dada a cada um desses direitos colidentes, mas também avaliar a interação entre eles considerando o suporte fático que proporcionou seu choque.

Nesse diapasão, o direito constitucional individual à liberdade religiosa compreende a tutela de três direitos: o da liberdade de crença, o da liberdade de culto e o da liberdade de organização religiosa (SILVA NETO, 2008). Previsto no artigo 5º VI da Constituição Cidadã, a liberdade de crença e de consciência assegura aos cidadãos tanto o direito de crer e professar sua fé sobre o que quiser, proibida a interferência do Estado ou de outros indivíduos, quanto o de não crer e divulgar sua descrença com quem e como bem desejar, desde que respeitadas as https://revistas.pucsp.br/index.php/DDEM| Nº. 02 | p.51-77| Jan. / Jun. 2021 
Augusto César Leite de Resende; Carlos Augusto Alcântara Machado e Lara Costa Barroso Andrade de Oliveira

normas de ordem pública (SILVA NETO, 2008). Afirma-se, por isso, que tal liberdade possui aspecto positivo e negativo, respectivamente, e que ambas as configurações são juridicamente protegidas (SILVA NETO, 2008). A esse respeito,

Os direitos humanos e os direitos fundamentais, sejam eles direitos de primeira, segunda ou terceira dimensão, inclusive as liberdades de crença, de religião e de culto, implicam para o Poder Público as obrigações constitucionais e convencionais, a saber: a) de respeitar o direito, ou seja, de não os violar, através de sua conduta; b) de protegê-los das agressões de terceiros e c) de satisfazê-los, cujos casos de violações decorrem, como regra, de omissões da Administração Pública. (RESENDE, 2018b, p. 290).

A Constituição Federal consagra ainda a liberdade de culto, a qual garante ao indivíduo o direito de celebrar suas convicções, religiosas ou não, da forma que desejar, igualmente certificada a preservação dos locais de manifestação e as liturgias (SILVA NETO, 2008). Assim como a liberdade anterior, essa encontra limite nos interesses de ordem pública, pois seu exercício não deve restringir, ingerir ou impedir o direito de outrem de fazer o mesmo ou diferente (SILVA NETO, 2008). Já a liberdade de organização religiosa consiste na permissão constitucional para os fiéis criarem e estruturarem segmento religioso, vedado aos entes federativos embaraçar-lhes o funcionamento ou manter relação de dependência, exceto quando esta advir de interesse público, consoante cláusula normativa presente no artigo 19, I, da Lex Fundamentalis. (SILVA NETO, 2008).

Essa configuração de proteção abrangente à liberdade religiosa, a qual abarca a liberdade de crença, culto e organização religiosa, existe desde a primeira constituição republicana e decorre diretamente da laicidade do Estado brasileiro (SILVA NETO, 2008). A relação de separação entre poder político e poder espiritual obriga àquele o não favorecimento a segmento religioso específico, situação que não poderia ocorrer, por exemplo, na Carta de 1824, a qual preferia o Catolicismo enquanto religião oficial (SILVA NETO, 2008).

A seu turno, o direito social à saúde, previsto tanto no artigo $6^{\mathrm{a}}$, caput, quanto no art. 196 e seguintes da Constituição Federal de 1988, compreende dever estatal de garantir não só a cura e a prevenção de enfermidades aos seus cidadãos - visão organicista da saúde -, mas também a promoção do seu bem-estar mental, físico e social. Essa última dimensão, diferentemente das outras, trata-se de 'imagem-horizonte', cuja concretização plena, apesar de inalcançável, define objetivo ao qual sempre se deve almejar (SCHWARTZ, 2001).

Em outras palavras, efetivar em sua integralidade a dimensão promocional do direito à saúde não é medida factível, porque bem-estar e qualidade de vida são conceitos abstratos e mutáveis de acordo com a vivência individual. Por isso, essa proposta deve servir de ideal a se https://revistas.pucsp.br/index.php/DDEM| Nº. 02 |p.51-77 | Jan. / Jun. 2021 
buscar uma aproximação constante em compatibilidade com a realidade de cada paciente e não um fim absoluto (SCHWARTZ, 2001). Tal conceito tem relação direta com o princípio da autonomia do paciente, tendo em vista que ao exercê-lo, o enfermo define o que melhor atende a sua felicidade e conforto (PALMA, 2019).

Entende-se como princípio da autonomia do paciente o reconhecimento do particular enquanto ser capaz de e livre para "decidir sobre ou buscar algo que seja melhor para si segundo os seus próprios valores", sem a influência de fatores externos e com o devido conhecimento de suas opções (PALMA, 2019). Assim, nota-se que a escolha do enfermo deve ser considerada e acatada pelos profissionais da saúde sempre que encontrar fundamento técnico-científico e for adequado para o tratamento da doença que está acometido ${ }^{7}$ (PALMA, 2019).

Germano Schwartz (2001, p. 43) define saúde, segundo os preceitos constitucionais brasileiros como:

um processo sistêmico que objetiva a prevenção e cura de doenças, ao mesmo tempo que visa a melhor qualidade de vida possível, tendo como instrumento de aferição a realidade de cada indivíduo e pressuposto de efetivação a possibilidade de esse mesmo indivíduo ter acesso aos meios indispensáveis ao seu particular estado de bem-estar.

Ademais, o direito à saúde no Brasil é regido pelos princípios da universalidade e igualdade de acesso (art. 196 - CF) e concretizado mediante rede regionalizada e hierarquizada, organizada em um sistema, o Sistema Único de Saúde (art. 198 - CF), conhecido como SUS (BRASIL, 1988). Enquanto o princípio da universalidade indica o acesso ao serviço público e gratuito de saúde a todos que dele necessitem (LORGA, 2015), o princípio da igualdade, aqui compreendida enquanto igualdade material, busca assegurar tratamento isonômico em dignidade aos que, por alguma razão, desigualam-se (FIGUEIREDO, 2007). Juntos, estabelecem o direito de todos, sem distinção, usufruírem do serviço de saúde. Nesse toar, o SUS operacionaliza e concretiza o direito constitucional à saúde, à medida que distribui as competências dos entes federativos para sua efetivação e estrutura a relação entre eles para melhor funcionamento da rede pública de saúde ${ }^{8}$ (BRASIL, 1990).

\footnotetext{
${ }^{7}$ Não à toa, o Código de Ética Médica - Resolução CFM n ${ }^{\circ}$ 1.931, de 17 de setembro de 2009 (2010) veda aos médicos tanto a aplicação de tratamento sem consentimento do paciente ou de seu representante legal após o esclarecimento do procedimento a ser realizado, ressalvado os casos de risco iminente de morte (art. 22); quanto a imposição entrave ao exercício do direito de livre decisão do enfermo sobre sua pessoa e seu bem-estar e, de igual modo, a utilização de sua autoridade para limitá-lo (art. 24).

${ }^{8}$ Acerca da distribuição de competências entre os entes federativos para concretização do direito à saúde, o art. 23, II, da Carta Magna de 1988, determina ser comum entre União, Estados, Distrito Federal e Municípios o dever de cuidar da saúde. Por sua vez, o seu art. 30, VII, reserva a esses últimos a competência para prestar serviços de Revista Direitos Democráticos \& Estado Moderno | Faculdade de Direito da PUC-SP https://revistas.pucsp.br/index.php/DDEM | No. 02 | p.51-77 | Jan. / Jun. 2021
} 
Augusto César Leite de Resende; Carlos Augusto Alcântara Machado e Lara Costa Barroso Andrade de Oliveira

Compreendidos os direitos à liberdade religiosa e à saúde em apartado, torna-se imprescindível o entendimento de denominador comum não só a eles, mas a todos direitos fundamentais, em menor ou maior grau, direta ou indiretamente, qual seja: a dignidade da pessoa humana (SARLET, 2012). Fundamento da república brasileira, conforme consta no art. $1^{\circ}$, inciso III da Lex Fundamentalis, a dignidade da pessoa humana é "valor fonte de todos os outros valores constitucionalmente postos" (SILVA NETO, 2008, p. 112), responsável tanto por impor unidade de sentido à ordem constitucional, quanto por legitimá-la (SARLET, 2012). Assim, conceitua Ingo Wolfgang Sarlet (2005, p. 37) como dignidade da pessoa humana:

[...] a qualidade intrínseca e distintiva reconhecida em cada ser humano que o faz merecedor do mesmo respeito e consideração por parte do Estado e da comunidade, implicando, neste sentido, um complexo de direitos e deveres fundamentais que assegurem a pessoa contra todo e qualquer ato de cunho degradante e desumano, como venham a lhe garantir as condições existenciais mínimas para uma vida saudável, além de propiciar promover sua participação ativa e co-responsável nos destinos da própria existência e da vida em comunhão com os demais seres humanos.

A relação deste princípio-pilar com os direitos fundamentais, portanto, é não só de razão de ser, mas também de fim precípuo, pois se por um lado a dignidade humana é fundamento para a existência destes, por outro, os direitos fundamentais são ferramentas para concretizá-la (SARLET, 2012). Há, desse modo, uma indissociabilidade entre eles, a qual, por consequência lógica, também é afeta à liberdade religiosa e à saúde, considerado o status de ambos bens da vida enquanto fundamentais.

No que se refere à liberdade religiosa, sua conexão com a dignidade humana é vislumbrada diretamente no que a espiritualidade representa para o indivíduo, que vai desde a forma de explicar o mundo e o que nele ocorre, até a formação de valores morais e éticos (SILVA NETO, 2008). Enfim, “o princípio da dignidade humana é o alicerce da liberdade de escolha da religião ou seita religiosa, da liberdade de mudar de religião, da liberdade de descrença e da liberdade de manifestação exterior da fé” (RESENDE, 2018b, p. 289).

Logo, privar alguém de crer ou de expressar sua fé e/ou obrigá-lo a seguir consciência distinta da que acredita macularia a sua essência humana de poder comandar sua vida como entende ser coerente e ser reconhecido e respeitado por isso (SARLET, 2005). E, neste caso, a violação à dignidade humana através da liberdade religiosa pode ser notada, a caráter exemplificativo, em duas das dimensões da dignidade idealizadas por Ingo Wolgang Sarlet

atendimento à saúde da população mediante cooperação técnica e financeira do ente federal e do estadual (BRASIL, 1988).

Revista Direitos Democráticos \& Estado Moderno|Faculdade de Direito da PUC-SP https://revistas.pucsp.br/index.php/DDEM | No. 02 | p.51-77| Jan. / Jun. 2021 
(2005): a ontológica e a relacional. A primeira delas, refere-se à qualidade do indivíduo "que se manifesta singularmente na autodeterminação consciente e responsável da própria vida e que leva consigo a pretensão de respeito por parte dos demais" (SARLET, 2005, p. 21). A segunda, por sua vez, manifesta-se no reconhecimento à mencionada pretensão por outrem e pelo Estado, isto é, na percepção fraterna do outro enquanto sujeito igual em dignidade e direitos (SARLET, 2005).

A ligação entre o direito à saúde e o princípio-pilar, a seu turno, não se limita à segurança contra enfermidades, seja em caráter preventivo ou curativo, atinge a dimensão promocional de alcance do bem-estar (FIGUEIREDO, 2007). Isto, porque não basta a garantir a sobrevivência do indivíduo, deve-se assegurar, também, circunstâncias para que ele exista dignamente após (BRASIL, 2017). Não à toa, como conclui Mariana Filchtiner Figueiredo (2007), o próprio conceito de dignidade humana construído por Ingo Wolfgang Sarlet (2005), citado em alhures, faz menção a uma vida saudável.

Ante ao explanado, rememoram-se as condições fáticas do Recurso Extraordinário $\mathrm{n}^{\mathrm{o}}$ 979.742: a necessidade de realização de procedimento de saúde não emergencial pelo Estado; a convicção religiosa da paciente, proibitiva de transfusão de sangue; a indisponibilidade de tratamento na rede pública compatível com esta crença; a inexistência de prova quanto à impossibilidade de realização do tratamento sem transfusão sanguínea, bem como quanto à existência de fila de espera com cidadãos em igual quadro clínico e no aguardo da execução de procedimento de mesma natureza; e previsão em técnica médica de método harmônico às exigências religiosas da paciente (BRASIL, 2017).

Sob esse suporte fático, é possível chegar à conclusão de que a colisão principiológica entre liberdade religiosa e saúde é apenas aparente, pois as condições fáticas às quais estão submetidas não as leva à oposição. O custeio do Estado a tratamento alternativo para a paciente sem uso de sangue garante a ela ambos os direitos fundamentais, sem que seja necessária a cedência em peso de um ao outro. Deste modo, não ocorre comprometimento do acesso isonômico do restante da população ao serviço de saúde, a priori, pela carência de provas de que o financiamento estatal faria a demandante burlar fila de pacientes em espera e, a posteriori, porque, ao contrário do aduzido pelo ente recorrente, ofertar procedimentos sem uso de sangue apresenta-se como forma de concretizar a igualdade material na seara em questão, tendo em vista que sem oportunizar tratamento dessa natureza, dificilmente Testemunhas de Jeová poderiam efetivar o seu direito à saúde. 
Augusto César Leite de Resende; Carlos Augusto Alcântara Machado e Lara Costa Barroso Andrade de Oliveira

Explica-se: o direito constitucional à igualdade é garantido sob as perspectivas formal e material. Enquanto aquela resguarda o tratamento isonômico de todos perante a ordem jurídica, esta o reserva em oferta de oportunidades (CUNHA JÚNIOR, 2015). Assim, é permitido ao Estado a imposição de critério discriminatório positivo com intuito de que grupos historicamente em situação de desigualdade alcancem a igualdade material (CUNHA JÚNIOR, 2015). In casu, a disponibilização de terapia diferenciada às Testemunhas de Jeová em virtude de seu credo apresenta-se como um modo de atender às garantias constitucionais.

Pela análise dos direitos fundamentais supostamente conflitantes a partir de suas espécies normativas e do contexto fático que os cercam, entende-se que é possível e, por conseguinte, é dever do Estado assegurar a liberdade religiosa e o direito à saúde no caso do RE $n^{\circ}$ 979.742, sem necessitar o sacrifício de parte de qualquer um dos dois. No entanto, este não é o único fundamento para solução da questão constitucional favorável à disponibilização de tratamento alternativo às Testemunhas de Jeová. É imprescindível, também, compreender a influência do princípio jurídico da fraternidade para guarida dos direitos de minorias sociais, sobretudo à religiosa supracitada e avaliar o custo-efetividade de tratamentos sem uso de sangue.

\section{A FRATERNIDAdE COMO PRINCÍPIO JURÍdico NA PROTEÇÃo DAS MINORIAS SOCIAIS}

Para o cristianismo, a fraternidade revela-se na responsabilidade de um irmão com outro dentro da comunidade, sob a premissa de que todos nela inseridos são filhos de um mesmo Deus. Por sua vez, para a filosofia, a fraternidade manifesta-se no âmbito público e político, como ideal ético de compreensão dos outros cidadãos como amigos e iguais (JABORANDY, 2017). Para o direito brasileiro, no entanto, a fraternidade ostenta o papel de princípio jurídico, que, idealizado no preâmbulo da Carta Magna de 1988, é concebido e extraído diretamente dos objetivos da República por ela fixados em seu art. $3^{\circ}$, especificamente no inciso I (MACHADO, 2017) ${ }^{9}$, e recebe três funções principais: a de equilíbrio da liberdade e a igualdade; a de reconhecimento; e a de interpretação (JABORANDY, 2017).

\footnotetext{
${ }^{9}$ No preâmbulo da Lex Fundamentalis (1988) consta compromisso da Assembleia Nacional Constituinte, na figura de representante da vontade do povo, para a construção de uma sociedade fraterna, pluralista e sem preconceitos. $\mathrm{O}$ seu art. $3^{\circ}$, I, a seu turno, determina que a construção de uma sociedade livre, justa e solidária é um dos objetivos da República Federativa do Brasil.

Revista Direitos Democráticos \& Estado Moderno |Faculdade de Direito da PUC-SP https://revistas.pucsp.br/index.php/DDEM| Nº. 02 |p.51-77 | Jan. / Jun. 2021
} 
A primeira função da fraternidade nasce da interação intersubjetiva entre os direitos individuais à liberdade e à igualdade, isto é, do diálogo conflitante entre ações particulares de seres humanos distintos, sujeitos dos mesmos direitos. Nessa situação, a fraternidade atua como balança com a finalidade de equilibrar os interesses das partes, ao ressignificar os conceitos dos direitos fundamentais supramencionados. Já a segunda, base para existência da anterior, referese à função fraternal de livre reconhecimento do outro enquanto ser humano, igual em direitos e dignidade e, por conseguinte, da responsabilidade individual e do Estado existente para com ele e vice-versa. Noutro giro, a terceira função da fraternidade a vislumbra como critério hermenêutico utilizado na interpretação e efetivação de outras regras (JABORANDY, 2017).

Dessa forma, pontua Clara Cardoso Machado Jaborandy (2017, p. 61):

No direito há integração das condutas, de sorte que haverá direitos para uns frente aos deveres de outros em perfeita correspondência. Infere-se daí a noção de bilateralidade, coparticipação, reciprocidade, que dá espaço à fraternidade, haja vista a relação jurídica ser sempre relação sujeito/sujeito.

Como se observa, a fraternidade, sobretudo em seu viés jurídico, anuncia-se numa perspectiva transindividual, na medida em que se destaca e é concretizada interpessoalmente e objetiva o despertar para dever recíproco de um humano para com o próximo (JABORANDY, 2017). Nesse sentido, possui forte conexão com as minorias sociais, tanto por integrar a mesma dimensão de direitos fundamentais, quanto por representar fundamento essencial para defesa delas (JABORANDY, 2017).

Define-se como minoria social todo grupo humano que, inserido em um Estado, possui características distintas da população em situação dominante e, em virtude delas, tem seus direitos negados ou restringidos (LOPES, 2008). Insta salientar que a ideia de minoria e de maioria social não está relacionada, necessariamente, com o quantitativo de indivíduos que compõem cada um desses conjuntos (LOPES, 2008), mas tão somente com a relação desvantajosa e discriminatória que aquele recebe em razão deste (CHAVES, 1971). A nomenclatura, portanto, retrata polarização de poder (CHAVES, 1971).

Assim, a conexão existente entre a efetivação dos direitos de minorias e a fraternidade melhor se evidencia da seguinte forma: ao reconhecer um grupo minoritário e os indivíduos que o integram enquanto sujeitos dignos de direitos, o Estado e a sociedade assumem a responsabilidade de assegurá-los; para tanto, é necessária a observância da igualdade material, a qual, compreendida sob o viés do pluralismo e do multiculturalismo, permite a imposição de critérios discriminatórios positivos para sua materialização (JABORANDY, 2017). Observa- 
Augusto César Leite de Resende; Carlos Augusto Alcântara Machado e Lara Costa Barroso Andrade de Oliveira

se, desse modo, a atuação das funções do princípio jurídico da fraternidade para garantir aos dominados o mesmo tratamento e as mesmas oportunidades dos dominantes.

As Testemunhas de Jeová, por apresentarem desvantagens frente a religiões dominantes e enfrentarem discriminação pelas peculiaridades de seu credo, sobretudo pela convicção de não recebimento de sangue transfundido, enquadram-se no conceito de minoria social ${ }^{10}$. Em relação à situação de desigualdade de poder, parte é inferida pelo seu baixo número de fiéis no Brasil - identificado pelo site oficial mundial de Testemunhas de Jeová, em 2019, em 869.537 evangelizadores (2019d) ${ }^{11}$ e pelo IBGE, no Censo demográfico de 2010, em 1.393.208 e parte, pela crença de neutralidade política adotada, sob a qual as Testemunhas de Jeová não votam, nem tampouco concorrem a eleição (JW, 2019f), o que dificulta a representatividade do grupo e suas pautas nesse meio.

A respeito da discriminação sofrida por essa minoria, esta pode ser explicada pelas noções de estigma e identidade social. A identidade social, que pode ser virtual ou real, referese ao conjunto de atributos exteriorizados pelo ser humano, os quais, reconhecidos pela sociedade, são utilizados para categorizá-lo dentro de um modelo padronizado do que esta considera "comum" ou "normal" para os detentores das mesmas características. Essa imagem exterior criada do julgamento da sociedade, chamada de identidade social virtual, por vezes não corresponde à real. Assim, quando alguém apresenta atributos diferentes do conhecido e classificado pela sociedade, ele é estigmatizado socialmente (MELO, 2020).

A seu turno, estigma social é "um atributo que produz um amplo descrédito na vida do sujeito", pois o vincula a ideia de mal ou ameaça à sociedade. Nesse sentido, qualificado de tal modo, o indivíduo é marginalizado e impedido de acessar as mais diversas oportunidades que os considerados "normais" têm (MELO, 2020, p. 2). Observa-se, dessa forma, a relação entre os estigmatizados e as minorias, na medida que a exclusão social dos primeiros proporciona negativa e/ou restrição de direitos, como as sofridas pelos segundos.

Nesse contexto, explica Zélia Maria de Melo (2020, p. 2):

Para os estigmatizados, a sociedade reduz as oportunidades, esforços e movimentos, não atribui valor, impõe a perda da identidade social e determina uma imagem deteriorada, de acordo com o modelo que convém à sociedade. $\mathrm{O}$ social anula a individualidade e determina o modelo que interessa para manter o padrão de poder, anulando todos os que rompem ou tentam romper

\footnotetext{
${ }^{10}$ Segundo os dados da Tabela 1.4.1 - População residente, por situação do domicílio e sexo, segundo os grupos de religião - Brasil - 2010 do IBGE (2010), a religião Católica Apostólica Romana é a que possui mais fiéis no país, com 123.280.172, seguida pelas Evangélicas com 42.275.440.

${ }^{11}$ Explica o site oficial mundial das Testemunhas de Jeová (2019e) que são considerados evangelizadores os cristãos que têm a comissão e a obrigação de pregar as boas novas do Reino de Deus.
}

Revista Direitos Democráticos \& Estado Moderno |Faculdade de Direito da PUC-SP https://revistas.pucsp.br/index.php/DDEM| Nº. 02 | p.51-77 | Jan. / Jun. 2021 
com esse modelo. O diferente passa a assumir à categoria de "nocivo", "incapaz", fora do parâmetro que a sociedade toma como padrão.

Portanto, as crenças singulares das Testemunhas de Jeová, em especial a contra transfusão sanguínea, apresentam-se como "marcas" sociais discriminatória ${ }^{12}$, no sentido de que as afasta do categorizado como "habitual" à maioria da população (CARVALHO; CAMPOS, 2016). A tentativa de assegurar o direito da minoria religiosa em questão à realização de terapia compatível com sua fé, embasa-se no alcance daquilo que a Constituição Federal vigente desde seu preâmbulo planejou: a construção de uma sociedade fraterna. Nesse toar, a resolução da questão jurídica presente no Recurso Extraordinário no 979.742 deve manter-se favorável a paciente demandante.

\section{O CUSTO-EFETIVIDADE DE TRATAMENTOS SEM USO DE SANGUE}

Apesar da análise de preponderância entre princípios e do estudo da fraternidade serem suficientes para solucionar a controvérsia constitucional do caso em evidência, a fim de reforçar o entendimento a favor das necessidades religiosas das Testemunhas de Jeová, faz-se a avaliação do custo-efetividade da disponibilização e manejo de tratamentos sem uso de sangue ante as outras opções terapêuticas, em consideração à possibilidade do Estado arcar com seus custos.

É cediço na literatura médica que a realização de transfusão sanguínea é medida arriscada, ainda que com diagnóstico e administração precisos, tanto pela possibilidade de contaminação, quanto pela de reações adversas ao recebimento do tecido (AZEVEDO, 2010), sendo este um dos motivos pelos quais, desde 2010, a Organização Mundial de Saúde promove a disponibilização de procedimentos alternativos ao seu uso, conforme debatido e determinado na Resolução WHA63.12 da 63ª Assembleia Mundial de Saúde (WHO, 2010) ${ }^{13}$. Dentre os tratamentos estimulados, citam-se as terapias focadas no gerenciamento e conservação do sangue do paciente, abordagem conhecida como Patient Blood Management (PBM). É dessas técnicas que as Testemunhas de Jeová se valem para receber cuidados médicos compatíveis com suas convicções.

\footnotetext{
${ }^{12}$ Em sua origem, estigma era verdadeira marca física imposta ao corpo dos socialmente excluídos, a fim de simbolizar a categoria em que estes se enquadravam aos demais e alertá-los para evitar contato (MELO, ?).

${ }^{13}$ Essa resolução levou em consideração os parcos recursos dos países em desenvolvimento para manter serviços de gerenciamento sanguíneo e sua qualidade, bem como os constantes esvaziamentos de bancos desse tecido (WHO, 2010).

Revista Direitos Democráticos \& Estado Moderno |Faculdade de Direito da PUC-SP https://revistas.pucsp.br/index.php/DDEM | No. 02 | p.51-77 | Jan. / Jun. 2021
} 
Augusto César Leite de Resende; Carlos Augusto Alcântara Machado e Lara Costa Barroso Andrade de Oliveira

Patient Blood Management alicerça-se em três pilares: o primeiro, pré-operatório, consiste na adequação da massa eritrocitária ou de hemoglobina através do diagnóstico prévio de deficiência de ferro e seu tratamento; o segundo, intraoperatório, baseia-se na redução ao máximo de perda de sangue por meio de medicamentos, equipamentos e procedimentos; e o terceiro, pós-operatório, funda-se no aperfeiçoamento da tolerância do paciente às consequências da perda de sangue (ASSUNÇÃO, 2018). A ideia do programa é evitar a transfusão do referido tecido, ao trabalhar com foco no sujeito do tratamento e suas condições fisiológicas de reação.

Essa alternativa tem se mostrado não só efetiva na cura das enfermidades, com resultados significantes comparados aos resultantes de transferência de tecido sanguíneo, mas também menos custosa. Por lidar somente com sangue advindo do próprio indivíduo, as terapias de PBM apresentam número reduzido de complicações, morbidade e mortalidade, consequentemente, menor é o tempo de estadia do paciente no hospital e a chance de readmissão nas Unidades de Tratamento Intensivo (HOFMANN et. al, 2013). Tal medida, sozinha, já é responsável por grande economia, tendo em vista a diferença entre os valores que seriam gastos com o mesmo paciente acaso tivesse sido realizada a transfusão sanguínea e este permanecesse sob o cuidado hospitalar para recuperar-se ${ }^{14}$.

Entretanto, essa não é a única vantagem de não se utilizar de transfusões. O financiamento de bolsas de sangue, ainda que advindas de doações, é caro, em virtude do alto preço do armazenamento, processamento e da execução de testes de qualidade e segurança do tecido (HOFMANN et al., 2013). No Brasil, por exemplo, o litro dessa substância, em 2011, chegava a custar até $\mathrm{R}$ \$1.500,00 pela rede pública de saúde (SEGATTO, 2011). Assim, a opção por tratamentos sem sangue reduz o gasto dos hospitais sem, no entanto, comprometer a qualidade do cuidado com o enfermo e sua cura.

A critério ilustrativo, cita-se o caso da Clínica e Hospital de Stanford, na Califórnia, cuja redução de transfusões sanguíneas por dezoito meses, a começar em julho de 2010, resultou em uma economia de 1,6 milhões de dólares; na redução de estadia de pacientes de 10,1 dias para 6,2; e na diminuição da mortalidade entre as pessoas que seriam transfundidas para 3,3\%, em consideração à taxa anterior de 5,5\% (ANTHES, 2015).

\footnotetext{
${ }^{14}$ Depois de três meses de utilização de métodos de Patient Blood Management em cirurgias de revascularização do miocárdio, foram comparadas cem cirurgias consecutivas em que tal método fora aplicado com outras cem, de casos similares aos operados, nos quais houve transfusão sanguínea. Como resultado, percebeu-se uma economia de \$387.070 cuja principal causa fora a redução de tempo de estadia do paciente no nosocômio (HELM et al., 1998 apud HOFMANN et al., 2013).
}

Revista Direitos Democráticos \& Estado Moderno | Faculdade de Direito da PUC-SP https://revistas.pucsp.br/index.php/DDEM | No. 02 | p.51-77| Jan. / Jun. 2021 
Nesse contexto, observa-se que aplicação das técnicas de Patient Blood Management é maneira menos custosa e, a seu modo, mais efetiva de curar e prevenir enfermidades que as que exigem transfusão de sangue. Por isso, o argumento aduzido na controvérsia constitucional sobre a onerosidade que o financiamento de tratamentos alternativos sem uso do tecido supramencionado traz ao Estado, ante a sua indisponibilidade na rede pública, não se sustenta sozinho. Carece de provas quanto a sua ocorrência no caso concreto, tendo em vista a extensiva prova científica e empírica de economia pecuniária nas situações em que não foi realizada a transferência sanguínea.

Além disso, é de se considerar que o direito à liberdade de crença ou religião e o direito à liberdade de culto não são direitos absolutos (RESENDE, 2018b), devendo-se, no entanto, reconhecer que a imposição de tratamento com transfusão de sangue às Testemunhas de Jeová em nome do direito à saúde viola o princípio da proporcionalidade, acarretando, por esse motivo, uma limitação não autorizada pela Constituição ao direito à liberdade religiosa.

A solução do aparente conflito entre o direito à liberdade religiosa e o direito à saúde dos fiéis Testemunhas de Jeová deve levar em consideração que a limitação aos direitos fundamentais, somente se dá, como diz Amanda Costa Thomé Travincas (2010, p. 4.688), de modo condicionado, cuja previsão tem como causa primeira a necessidade de proteger a eficácia dos direitos da atividade erosiva do Estado, ou seja, "há limites aos limites dos direitos humanos e dos direitos fundamentais" (RESENDE, 2018b, p. 296).

Nesse contexto, a restrição ao direito fundamental à liberdade somente será legítima se observado o princípio da proporcionalidade, que é considerado verdadeiro limite material à atividade restritiva de direitos fundamentais, especialmente quando a limitação decorrer de conflito entre eles (RESENDE, 2018b). A esse respeito, Aharon Barak (2015, p. 11) leciona que "A constitucionalidade de tal limitação é decidida de acordo com as regras da proporcionalidade" 15 , ou, dito de outra forma, "Um direito relativo é um direito que não é protegido em todo seu alcance. Pode ser limitado. Nem toda limitação constitui uma violação. As limitações são constitucionais se forem proporcionais"16 (BARAK, 2015, p. 12).

O princípio da proporcionalidade é, como visto, instrumento necessário para aferir a legitimidade dos atos estatais que restringem direitos fundamentais (PIEROTH; SCHILINK,

\footnotetext{
15 the constitutionality of such a limitation is decided according to the rules of proportionality (BARAK, 2015, p. 11, tradução livre).

${ }^{16}$ a relative right is a right that is not protected in its full scope. It can be limited. Not every limitation constitutes a violation. Limitations are constitutional if they are proportional (BARAK, 2015, p. 12, tradução livre).

Revista Direitos Democráticos \& Estado Moderno | Faculdade de Direito da PUC-SP https://revistas.pucsp.br/index.php/DDEM | No. 02 | p.51-77| Jan. / Jun. 2021
} 
2012), que se desdobra em três elementos, quais sejam: a) adequação; b) necessidade; e c) proporcionalidade em sentido estrito (SARLET, 2015).

A adequação impõe que as medidas restritivas a direitos (os meios) sejam aptas a proteger os direitos humanos e os direitos fundamentais de terceiros (os fins), ou seja, o meio deve promover o fim almejado (ÁVILA, 2013). A necessidade, por sua vez, consiste na escolha, dentre os meios disponíveis e igualmente adequados para promover o fim, daquele menos oneroso e lesivo aos direitos fundamentais afetados (ÁVILA, 2013). E a proporcionalidade em sentido estrito exige que as vantagens da interferência na esfera dos direitos dos cidadãos superem os ônus decorrentes da limitação a direitos fundamentais, ou seja, o benefício alcançado com a adoção da medida restritiva não deve sacrificar direitos fundamentais mais importantes axiologicamente do que os direitos que a medida pretendeu preservar (MARMELSTEIN, 2011) ${ }^{17}$.

No caso em reflexão, interessa o requisito da necessidade. Com efeito, a realização de tratamento médico com o uso de sangue é adequada porque apto a alcançar o resultado pretendido, qual seja, a cura do paciente, mas, por outro lado, não é necessário, na medida em que existe um meio menos oneroso à liberdade religiosa das Testemunhas de Jeová, que é o tratamento alternativo sem a transfusão de material sanguíneo.

Sendo assim, impor o tratamento médico com o uso de material sanguíneo para pacientes Testemunhas de Jeová com o objetivo de garantir-lhes a cura e, por consequência, a efetividade do direito à saúde, mostra-se uma restrição desproporcional e, portanto, ilegítima do direito à liberdade religiosa dos referidos pacientes, uma vez que a ciência médica já colocou à disposição dos já referenciados enfermos tratamento conhecido como Patient Blood Management, em que há, como já ressaltado alhures, gerenciamento e conservação do sangue do próprio paciente e, destarte, sem transfusão de sangue.

\section{CONSIDERAÇÕES FINAIS}

O Recurso Extraordinário n 979.742 trouxe ao Supremo Tribunal Federal dúvida quanto à constitucionalidade de garantir à minoria religiosa das Testemunhas de Jeová tratamento alternativo, indisponível na rede pública de saúde, sem utilização de sangue às custas do Estado, sob o fundamento de que, de tal forma, haveria preferência a esse grupo frente à

\footnotetext{
${ }^{17}$ No mesmo sentido: RESENDE $\left(2018^{\mathrm{a}}\right)$.

Revista Direitos Democráticos \& Estado Moderno | Faculdade de Direito da PUC-SP https://revistas.pucsp.br/index.php/DDEM| Nº. 02 |p.51-77 | Jan. / Jun. 2021
} 
coletividade no que se refere ao acesso ao direito à saúde. No presente estudo, contudo, deduziuse que a lógica da indagação não deve prevalecer.

Inicialmente, devido ao resultado da análise da colisão entre os direitos fundamentais em questão, quais sejam, o à liberdade religiosa e o à saúde, a partir das espécies normativas que estes fazem parte. Pelos estudos do doutrinador e jurista Robert Alexy percebeu-se que os direitos fundamentais possuem duplo caráter normativo: são concomitantemente regra e princípio, manifestando-se como este último somente quando, diante de um caso concreto, representar oposição a outro princípio. Nessa hipótese, o confronto entre direitos fundamentais deve ser resolvido de igual modo a uma colisão principiológica, ou seja, através da análise da relação de precedência entre os princípios em tela na perspectiva do suporte fático que os contrapõem, de forma a prevalecer o de maior peso dentro das circunstâncias em foco.

Nesse toar, observada a íntima relação da proteção à liberdade religiosa com a dignidade humana, decorrente da influência da espiritualidade na formação do indivíduo, bem como a importância da autonomia do paciente na efetividade do aspecto promocional do direito à saúde, também associada ao princípio-pilar supracitado, frente às condições de fato que esculpem o caso recorrido, entende-se que a colisão entre esses direitos fundamentais é apenas aparente. Tal ilação advém da percepção de que, ao se patrocinar tratamento compatível com a religião da paciente (Testemunha de Jeová) previsto em técnica médica, garante-se à demandante direito à liberdade religiosa e à saúde sem necessitar que um ceda ao outro ou comprometer o acesso isonômico do restante da população ao direito à saúde.

Essa segunda conclusão, inclusive, não se limita à carência de comprovação de lista de espera de pacientes, com quadro clínico similar ao da autora, para recebimento da mesma terapia. Expande-se, com o entendimento de que assegurar às Testemunhas de Jeová intervenção médica em harmonia com suas convicções religiosas é ferramenta assecuratória do direito à igualdade em seu viés material, isto é, em oportunidades, para com outros credos. Assim, pelo resultado técnica de ponderação de interesses entre liberdade religiosa e saúde no caso em exame, compreende-se que ambos os direitos fundamentais podem ser garantidos pelo julgamento improcedente do Recurso Extraordinário nº 979.742.

Depois, pela influência do princípio jurídico da fraternidade e de suas funções no reconhecimento dos direitos das minorias sociais e na ressignificação dos direitos à liberdade e à igualdade. Entendeu-se que as minorias sociais são grupos historicamente dominados por possuírem características distintivas dos dominantes dentro da sociedade. Tais "marcas" sociais são compreendidas como estigmas e provocam a exclusão dos indivíduos que as possuem, tanto https://revistas.pucsp.br/index.php/DDEM| Nº. 02 | p.51-77| Jan. / Jun. 2021 
Augusto César Leite de Resende; Carlos Augusto Alcântara Machado e Lara Costa Barroso Andrade de Oliveira

socialmente, em oportunidades, quanto juridicamente, em direitos. Pela baixa quantidade de fiéis perante outras religiões; pela fé na neutralidade política; e pelo mau julgamento da sociedade quanto às suas crenças, sobretudo a de negação à transfusão sanguínea, notou-se que as Testemunhas de Jeová representam uma minoria dentro do meio religioso.

Nesse sentido, o princípio jurídico da fraternidade atua na relação interpessoal desses agrupamentos estigmatizados com o Estado e o restante da sociedade, como promotor do reconhecimento das responsabilidades recíprocas destes com aqueles, frente à assimilação da igualdade que têm em dignidade e direitos; e, por conseguinte, da igualdade material entre as minorias e as maiorias. Logo, o financiamento pelo Estado de tratamentos de saúde alternativos, compatíveis com a convicção religiosa das Testemunhas de Jeová de não transfusão sanguínea, é medida advinda de discriminação positiva, com a finalidade de igualar esse grupo minoritário em oportunidades e direitos ao majoritário e, ainda, em virtude da averiguação do melhor custoefetividade que as terapias sem uso de sangue apresentam frente as que o utilizam.

As técnicas de conservação e gerenciamento do sangue dos pacientes, conhecidas como Patient Blood Management (PBM), desde 2010, são promovidas pela Organização Mundial de Saúde e apresentam resultados mais efetivos na cura de doenças, além de serem financeiramente menos onerosos. Isto, porque, além do manejo de tecido pertencente somente ao paciente reduzir a quantidade de complicações em procedimentos de saúde e, como resultado, diminuir os índices de morbidade e mortalidade dos hospitais, abaixa, também, o tempo de estadia dos enfermos nos leitos e os gastos com o tratamento e conservação de bolsas de sangue. Dessa forma, sem concreta comprovação de que o custeio pelo Estado dessas terapias alternativas, ainda que não abarcadas pelo Sistema Único de Saúde, seria desvantajoso aos cofres públicos ao ponto de sacrificar a proteção à saúde do restante da coletividade, inexiste causa impeditiva para sua garantia às Testemunhas de Jeová.

Resta demonstrada, portanto, a constitucionalidade do pagamento de tratamentos pelo Estado, inexistentes na rede pública de saúde, que não se utilizam de transfusão sanguínea às Testemunhas de Jeová, à luz do questionado no Recurso Extraordinário no 979.742, é constitucional.

E a imposição de tratamento médico com transfusão de sangue apresenta-se como uma restrição desproporcional ao direito à liberdade religiosa das Testemunhas de Jeová, uma vez que a medicina colocou à disposição dos enfermos da aludida fé tratamento alternativo denominado Patient Blood Management (PBM), sem o uso, portanto, de material sanguíneo de terceiros e, desse modo, menos oneroso para a esfera da liberdade religiosa. 


\section{REFERÊNCIAS}

ABBOUD, Georges; CARNIO, Henrique Garbellini; OLIVEIRA, Rafael Thomaz. Introdução ao direito: teoria, filosofia e sociologia do direito. 4. ed. São Paulo: Revista dos Tribunais, 2019.

ALEXY, Robert. Teoria dos direitos fundamentais. Tradução Virgílio Afonso da Silva. São Paulo: Malheiros, 2008.

ANTHES, Emily. Evidence-based medicine: save blood, save lifes. Nature, v. 520, 2 apr. 2015, p. 24-26. Disponível em:

https://www.nature.com/news/polopoly_fs/1.17224!/menu/main/topColumns/topLeftColumn/ pdf/520024a.pdf. Acesso em: 28 out. 2019.

ASSUNÇÃO, Marcelo Froes. Avaliação do impacto institucional da implantação de um programa de Patient Blood Management, construção de um projeto educacional e revisão da literatura. 2018. 115f. Dissertação (Mestrado em Ciências). Ribeirão Preto: Faculdade de Medicina de Ribeirão Preto - Universidade de São Paulo, 2018. Disponível em: https://teses.usp.br/teses/disponiveis/17/17155/tde-13092018-

152847/publico/MARCELOFROESASSUNCAOCO.pdf. Acesso em: 27 out. 2019.

ÁVILA, Humberto. Teoria dos princípios: da definição à aplicação dos princípios jurídicos. 14. Ed. São Paulo: Malheiros, 2013.

AZEVEDO, Álvaro Villaça. Autonomia do paciente e direito de escolha de tratamento médico sem transfusão de sangue mediante os atuais preceitos civis e constitucionais brasileiros. Atualizado conforme o novo Código Ética Médica - Resolução CFM/1931, São Paulo: [s. n.], 2010.

BARAK, Aharon. Human dignity: the constitutional value and the constitutional right. Cambridge: Cambridge University Press, 2015.

BÍBLIA. Português. Bíblia Sagrada Ave Maria. São Paulo: Claretiana, 202. ed., 2013.

BRASIL. Constituição Política do Imperio do Brazil (de 25 de março de 1824). Brasília: Senado, 1824. Disponível em:

http://www.planalto.gov.br/ccivil_03/Constituicao/Constituicao24.htm. Acesso em: 26 fev. 2020.

BRASIL. Constituição da República Federativa do Brasil. Brasília: Senado, 1988.

Disponível em: http://www.planalto.gov.br/ccivil_03/Constituicao/Constituicao.htm. Acesso em: 7 set. 2019.

BRASIL. Lei $\mathbf{n}^{\mathbf{0}}$ 8.080, de 19 de setembro de 1990. Dispõe sobre as condições para a promoção, proteção e recuperação da saúde, a organização e o funcionamento dos serviços correspondentes e dá outras providências. Brasília: Poder Executivo. Disponível em: http://www.planalto.gov.br/ccivil_03/leis/18080.htm. Acesso em: 9 out. 2019.

Revista Direitos Democráticos \& Estado Moderno |Faculdade de Direito da PUC-SP https://revistas.pucsp.br/index.php/DDEM | No. 02 | p.51-77 | Jan. / Jun. 2021 
Augusto César Leite de Resende; Carlos Augusto Alcântara Machado e Lara Costa Barroso Andrade de Oliveira

BRASIL. Supremo Tribunal Federal. RE 979.742 RG. Rel. Min. Luís Roberto Barroso, Tribunal do Pleno, julgado em 29 jun. 2017. Disponível em:

http://redir.stf.jus.br/paginadorpub/paginador.jsp?docTP=TP\&docID=13133236. Acesso em: 5 set. 2019.

BRASIL. Tribunal Regional Federal (1 ${ }^{\mathbf{a}}$ Região). AG 0017343-82.2016.4.01.0000. Relator: Desembargador Federal Kassio Nunes Marques. Brasília, publicado em 8 jul. 2016.

Disponível em:

https://arquivo.trf1.jus.br/PesquisaMenuArquivo.asp?p1=00173438220164010000. Acesso em: 13 out. 2019.

CARVALHO, Marco César de. CAMPOS, Tiago Rodrigues. O estigma religioso imposto às testemunhas de jeová no brasil em face da não aceitação da transfusão de sangue. Universitas Jus, Brasília, v. 27, n. 3, p. 156-172, 2016. Disponível em:

https://www.publicacoesacademicas.uniceub.br/jus/article/view/4423. Acesso em: 23 out. 2019.

CHAVES, Luís de Gonzaga Mendes. Minorias e seu estudo no Brasil. Revista de Ciências Sociais, Fortaleza, v. 1, n. 1, p. 149-168, 1970. Disponível em:

http://www.repositorio.ufc.br/bitstream/riufc/4487/1/1971_art_LGMChaves.pdf. Acesso em: 18 out. 2019.

CÓDIGO DE ÉTICA MÉDICA. Resolução CFM n 1.931, de 17 de setembro de 2009 (versão de bolso). Brasília: Conselho Federal de Medicina, 2010. Disponível em:

https://portal.cfm.org.br/images/stories/biblioteca/codigo\%20de\%20etica\%20medica.pdf. Acesso em: 7 out. 2019.

CUNHA JÚNIOR, Dirley da. Curso de direito constitucional. Conforme EC 84/14. Salvador: JusPodivm. 9. ed., rev, amp., atual., 2015.

DWORKIN, Ronald. Levando o direito a sério. Tradução de Nelson Boeira. 3. ed. São Paulo: WMF Martins Fontes, 2010.

FIGUEIREDO, Mariana Filchtiner. Direito fundamental à saúde: parâmetros para sua eficácia e efetividade. Porto Alegre: Livraria do Advogado, 2007.

HOFFMAN, A. et al. Economic consideration on transfusion medicine and patient blood management. Best Practice \& Research Clinical Anaesthesiology, v. 27, n. 1, p. 59-68, 2013. Disponível em: https://www.ncbi.nlm.nih.gov/pubmed/23590916. Acesso em: 29 out. 2019.

INSTITUTO BRASILEIRO DE GEOGRAFIA E ESTATÍSTICA. Censo demográfico de 2010 - Características gerais da população, religião e pessoas com deficiência. Disponível em:

https://biblioteca.ibge.gov.br/visualizacao/periodicos/94/cd_2010_religiao_deficiencia.pdf. Acesso em: 21 out. 2019. 
JABORANDY, Clara Cardoso Machado. O princípio jurídico da fraternidade: um instrumento para proteção de direitos fundamentais transindividuais. Rio de Janeiro: Lumen Juris, 2017.

JW, 2019a. O que a bíblia diz sobre transfusões de sangue? Disponível em: https://www.jw.org/pt/ensinos-biblicos/perguntas/biblia-transfusoes-desangue/\#?insight[search_id]=03320918-76c8-41ed-8647-

835a99d42ff2\&insight[search_result_index]=14. Acesso em: 5 set. 2019.

JW, 2019b. Bioética e lei. Disponível em: https://www.jw.org/pt/biblioteca-medica/leisbioetica-medica-transfusao-de-sangue/. Acesso em: 5 set. 2019.

JW, 2019c. Frações de sangue e procedimentos cirúrgicos. Disponível em: https://www.jw.org/pt/publicacoes/livros/amor-de-deus/fracoes-de-sangue-procedimentoscirurgicos/\#?insight[search_id]=b948c1cf-d724-4940-ac10-

6f8a6bd7e65e\&insight[search_result_index]=0. Acesso em: 5 set. 2019

JW, 2019d. Testemunhas de Jeová em todo mundo: Brasil. Disponível em: https://www.jw.org/pt/testemunhas-de-jeova/worldwide/BR/. Acesso em: 19 out. 2019.

JW, 2019e. Quem é evangelizador? Disponível em: https://www.jw.org/pt/biblioteca/revistas/w20000701/Quem-\%C3\%A9evangelizador/\#?insight[search_id]=2fa73860-c7d6-4e4d-bd91444c100467b3\&insight[search_result_index]=0. Acesso em: 19 out. 2019.

JW, 2019f. Por que as Testemunhas de Jeová são neutras em assuntos políticos? Disponível em: https://www.jw.org/pt/testemunhas-de-jeova/perguntasfrequentes/neutralidade-politica/. Acesso em: 19 out. 2019.

LOPES, Ana Maria D’Ávila. Proteção constitucional dos direitos fundamentais culturais das minorias sob a perspectiva do multiculturalismo. Revista de Informação Legislativa, v. 25, n. 177, jan/mar. 2008. Disponível em: http://www2.senado.leg.br/bdsf/handle/id/160330. Acesso em: 18 out. 2019.

LORGA, Carlos Alexandre. Saúde e desenvolvimento: a influência da universalidade e integralidade no desenvolvimento sustentável. Brasília: Conselho Nacional de Secretários de Saúde (CONASS), 2015. Disponível em: https://www.conass.org.br/biblioteca/pdf/colecao2015/CONASS-DIREITO_A_SAUDEART_7B.pdf. Acesso em: 9 out. 2019.

MACHADO, Carlos Augusto Alcântara. A fraternidade como categoria jurídica: fundamentos e alcance (expressão do constitucionalismo fraternal). Curitiba: Appris, 2017.

MARMELSTEIN, George. Curso de direitos fundamentais. 3. ed. São Paulo: Atlas, 2011.

MELO, Zélia Maria de. Os estigmas: a deterioração da identidade social. Disponível em: http://www.aedmoodle.ufpa.br/pluginfile.php/199228/mod_resource/content/1/identidade\%20 social\%20e\%20estigmas.pdf. Acesso em: 21 out. 2019. 
Augusto César Leite de Resende; Carlos Augusto Alcântara Machado e Lara Costa Barroso Andrade de Oliveira

NERY JÚNIOR, Nelson. Escolha esclarecida de tratamento médico por pacientes Testemunhas de Jeová como exercício harmônico de direitos fundamentais. Atualizado conforme o novo Código Ética Médica - Resolução CFM/1931. São Paulo: [s. n.], 2009.

PALMA, Homero de Aquino. Autonomia dos pacientes. Portal do Conselho Federal de Medicina, 19 jul. 2019. Disponível em:

https://portal.cfm.org.br/index.php?option=com_content\&view=article\&id=28290:autonomiados-pacientes\&catid=46:artigos\&Itemid=18_. Acesso em: 7 out. 2019.

PIEROTH, Bodo; SCHLINK, Bernhard. Direitos fundamentais. Tradução de António Francisco de Sousa e António Franco. São Paulo: Saraiva, 2012.

RESENDE, Augusto César Leite de. O dever de residência dos membros do Ministério Público: uma análise à luz do princípio da proporcionalidade. Fórum Administrativo - FA, Belo Horizonte, ano 18, n. 203, p. 16-24, jan. 2018a.

RESENDE, Augusto César Leite de. O futuro do Sistema Interamericano de Direitos Humanos é doméstico: diálogo e cooperação entre ordens jurídicas como modelos de empoderamento da Corte Interamericana de Direitos Humanos. Tese (Doutorado em Direito) - Programa de Pós-Graduação em Direito da Pontifícia Universidade Católica do Rio Grande do Sul. Porto Alegre, 260 p., 2019.

RESENDE, Augusto César Leite de Resende. Liberdade de culto e o sacrifício de animais em cerimônias religiosas afro-brasileiras: uma análise à luz da Constituição do Brasil. Revista de Direito Brasileira, São Paulo, v. 20, n. 8, p. 287-304, mai./ago. 2018 b.

SARLET, Ingo Wolfgang. A eficácia dos direitos fundamentais: uma teoria geral dos direitos fundamentais na perspectiva constitucional. 12. ed. Porto Alegre: Livraria do Advogado, 2015.

SARLET, Ingo Wolfgang. Dignidade da pessoa humana e direitos fundamentais na Constituição Federal de 1988. 9. ed. rev. atual. Porto Alegre: Livraria do Advogado, 2012.

SARLET, I. Wolfgang. Dimensões da dignidade da pessoa humana: construindo uma compreensão jurídico-constitucional necessária e possível. In: HÄBERLE, P. et al. Dimensões da dignidade - ensaios de filosofia do direito e Direito Constitucional. Porto Alegre: Livraria do Advogado, 2005, cap. 1, p. 13-43.

SCHWARTZ, Germano. Direito à saúde: efetivação em uma perspectiva sistêmica. Porto Alegre: Livraria do Advogado, 2001.

SEGATTO, Cristiane. A indústria do sangue. Revista Época, Colunas, Nossa Saúde, 17 jun. 2011. Disponível em: http://revistaepoca.globo.com/Revista/Epoca/0,_EMI242291-15230,00A+INDUSTRIA+DO+SANGUE.html. Acesso em 28 out. 2019.

SILVA NETO, Manoel Jorge e. Proteção constitucional à liberdade religiosa. Rio de Janeiro: Lumen Juris, 2008.

SOBRINHO, Wanderley Preite. Falta de médicos e de remédios: 10 grandes problemas da saúde brasileira. UOL, São Paulo, 19 mai. 2018. Disponível em: 
https://noticias.uol.com.br/saude/listas/falta-medico-e-dinheiro-10-grandes-problemas-dasaude-no-brasil.htm. Acesso em: 10 set. 2019.

TRAVINCAS, Amanda Costa Thomé. Procusto e o mito da forma: o conteúdo essencial como limite às restrições aos direitos fundamentais e o problema da redução da eficácia das normas. Anais do XIX Encontro Nacional do CONPEDI. Fortaleza: Fundação Boiteux, p. 4.677-4.702, 2010. Disponível em:

http://www.publicadireito.com.br/conpedi/manaus/arquivos/anais/fortaleza/3962.pdf. Acesso em: 07 dez. 2019.

WORLD HEALTH ORGANIZATION (WHO). Availability, safety and quality of blood products. Geneva: World Health Organization Sixty-third World Health Assembly, Agenda item 11.17, WHA63.12, 2010. Disponível em:

http://apps.who.int/gb/ebwha/pdf_files/WHA63/A63_R12-en.pdf. Acesso em: 17 out. 2019.

WORLD HEALTH ORGANIZATION (WHO). Global Forum for Blood Safety: Patient Blood Management. Dubai: Worl Health Organization, 2011. Disponível em:

https://www.who.int/bloodsafety/events/gfbs_01_pbm_concept_paper.pdf. Acesso em 17 out. 2019.

Recebido - 12/10/2020

Aprovado - 14/02/2021 